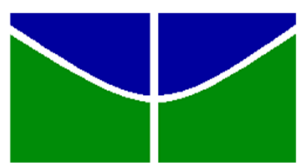

UNIVERSIDADE DE BRASÍLIA

Faculdade de Economia, Administração e Contabilidade - FACE

Departamento de Ciências Contábeis e Atuarias - CCA

Bacharelado em Ciências Contábeis

Sthelen Costa Almeida

DOMÍNIO DOS GRADUANDOS EM CIÊNCIAS CONTÁBEIS DA UNB SOBRE

PARTICULARIDADES DA CONTABILIDADE RURAL

BRASÍLIA, DF 


\section{Professora Doutora Márcia Abrahão Moura Reitora da Universidade de Brasília}

Professor Doutor Eduardo Tadeu Vieira Diretor da Faculdade de Economia, Administração e Contabilidade Professor Doutor José Antônio de França Chefe do Departamento de Ciências Contábeis

Professor Doutor Paulo Augusto Petenuzo Britto Coordenador de Graduação do curso de Ciências Contábeis - Diurno

Professor Mestre Elivânio Geraldo de Andrade Coordenador de Graduação do curso de Ciências Contábeis - Noturno 


\section{DOMÍNIO DOS GRADUANDOS EM CIÊNCIAS CONTÁBEIS DA UNB SOBRE PARTICULARIDADES DA CONTABILIDADE RURAL}

Trabalho de Conclusão de Curso (Monografia) apresentado ao Departamento de Ciências Contábeis e Atuariais da Universidade de Brasília, como requisito parcial à conclusão da disciplina Pesquisa em Ciências Contábeis e consequente obtenção do grau de Bacharel em Ciências Contábeis.

Orientador: Prof. Dr. José Alves Dantas 


\section{ALMEIDA, Sthelen Costa}

Domínio dos graduandos em ciências contábeis da UnB sobre particularidades da contabilidade rural - Sthelen Costa Almeida - Brasília, 2018.

Orientador(a): Prof. José Alves Dantas

Trabalho de Conclusão de curso (Monografia - Graduação) - Universidade de Brasília, Semestre de verão 2018.

1. Contabilidade Rural 2. Oferta de Disciplinas 3. Particularidades I. Departamento de Ciências Contábeis e Atuariais da Faculdade de Economia, Administração e Contabilidade da Universidade de Brasília. II. Título. 


\title{
DOMÍNIO DOS GRADUANDOS EM CIÊNCIAS CONTÁBEIS DA UNB SOBRE PARTICULARIDADES DA CONTABILIDADE RURAL
}

Trabalho de Conclusão de Curso (Monografia) apresentado ao Departamento de Ciências Contábeis e Atuariais da Universidade de Brasília, como requisito parcial à conclusão da disciplina Pesquisa em Ciências Contábeis e consequente obtenção do grau de Bacharel em Ciências Contábeis.

\author{
Prof. José Alves Dantas \\ Orientador \\ Departamento de Ciências Contábeis e Atuariais \\ Universidade Brasília (UnB) \\ Prof. Rosane Maria Pio da Silva \\ Examinador \\ Departamento de Ciências Contábeis e Atuariais \\ Universidade de Brasília (UnB)
}

\section{BRASÍLIA}


"Minha singela homenagem aos guerreiros trabalhadores do campo que, incansavelmente, de sol a sol alimentam o progresso e a população desse nosso Brasilzão abençoado por Deus." 


\section{AGRADECIMENTOS}

Agradeço ao professor José Alves Dantas por aceitar me orientar nos acréscimos do segundo tempo e pela paciência em todas as reuniões, quase natalinas, necessárias para elaboração deste trabalho.

Agradeço à professora Ducinele Botelho por me auxiliar na delimitação do tema para esta pesquisa e por me acompanhar durante ao longo do ano de 2017.

Agradeço ao meu parceiro Murillo Alves por me ajudar a formatar este trabalho diversas vezes, corrigir meus constantes erros ortográficos e especialmente por confiar na minha capacidade.

Agradeço a Deus por sempre proporcionar grandes oportunidades de crescimento em minha vida. 


\section{RESUMO}

O Brasil é um país continental com grande capacidade de produção agropecuária, tanto que agronegócio representa grande parcela da renda aqui produzida, desta forma o mercado exige que os profissionais responsáveis por auxiliar as tomadas de decisão neste setor apresentem conhecimento relevante sobre o tema. O estudo apresentou como objetivo identificar o conhecimento dos graduandos em Ciências Contábeis da UnB sobre especificidades da Contabilidade Rural. Para isso foi aplicado uma adaptação do questionário utilizado por Costa, Libonati e Rodrigues (2004), com questões que abordam particularidades da contabilidade rural. Foi realizada uma pesquisa do histórico de oferta de disciplinas que abordam o tema, a relevância do agronegócio para a economia brasileira e as particularidades que foram abordadas no questionário. A partir de uma análise sobre os percentuais de acerto apresentado pelos respondentes e o interesse que eles demonstram no assunto, bem assim com seu perfil. Foi observado que os alunos que cursaram a disciplina apresentaram maior conhecimento sobre os temas abordados, e que as questões que poderiam ser respondidas apenas com conhecimentos obtidos em contabilidade geral apresentaram maior porcentagem de acerto. A maioria dos respondentes considerou relevante a inclusão da disciplina na grade curricular do curso, porém poucos demonstraram interesse em realizar uma especificação na área.

Palavras-chave: Contabilidade Rural; Questionário; Oferta de disciplinas; Percentual de acerto. 


\begin{abstract}
Brazil is a continental country with great capacity of agricultural production, in which the agribusiness represents a large part of the income produced in the nation, in this way the market demands professionals responsible for helping the decision making in this sector who present a relevant knowledge on the subject. The study aimed to identify the knowledge of undergraduate students in Accounting from the University of Brasília on the specificities of Rural Accounting, for this was applied an adaptation of the questionnaire used by Costa, Libonati and Rodrigues (2004), with questions that deal with particularities of rural accounting. A survey was made about the historic of curricular offerings which work with the theme, the relevance of agribusiness to the Brazilian economy and the particularities that were addressed in the questionnaire. From an analysis of the percentage of correctness presented by the respondents and the interest they show in the subject and the percentage of correctness with the profile of the respondents, it was observed that the students who attended the course presented a higher percentage of correctness in relation to those who did not study it and that questions that could be answered only with knowledge obtained in general accounting presented a higher percentage of correctness. Most of the respondents considered the inclusion of the subject in the curriculum of the course relevant, however few students showed interest to pursue a specialization in the area.
\end{abstract}

Keywords: Rural Accounting; Questionnaire; Curricular offerings; Percentage of correctness. 


\section{LISTA DE TABELAS}

Tabela 1: Balança Comercial Brasileira e Balança Comercial do Agronegócio:1997 a 2016

Tabela 2: Perfil dos respondentes e interesse na área

Tabela 3: Nível geral de acerto

Tabela 4: Nível de acerto, de acordo com o perfil dos respondentes

Tabela 5: Nível de acerto, de acordo com o interesse no assunto 


\section{LISTA DE QUADROS}

Quadro 1- Tópicos abordados na disciplina Contabilidade Agrária, no $2^{\circ}$ semestre de 2017 
Sumário

1 INTRODUÇÃO

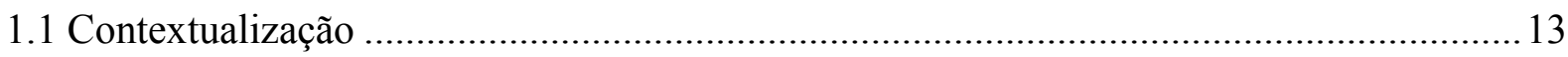

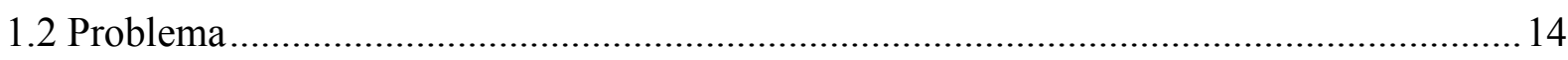

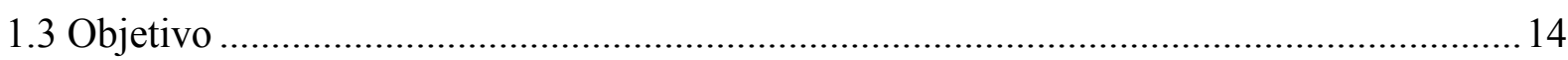

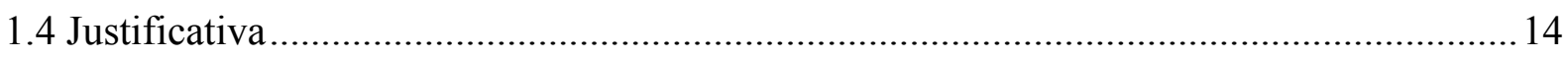

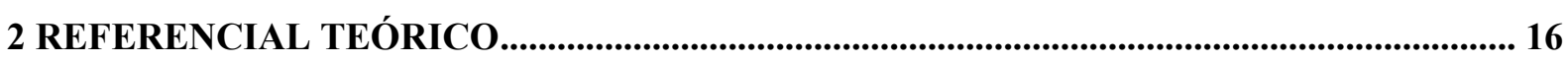

2.1 A importância do Agronegócio na Economia Brasileira .......................................................... 16

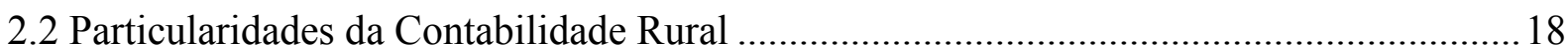

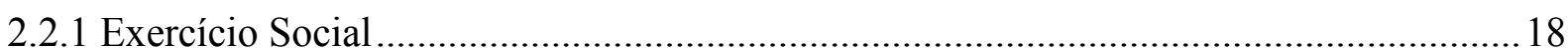

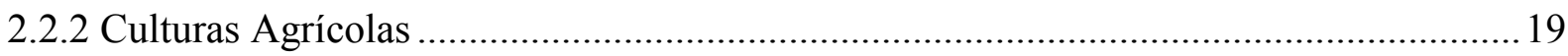

2.2.3 Amortização, Depreciação e Exaustão .........................................................................20

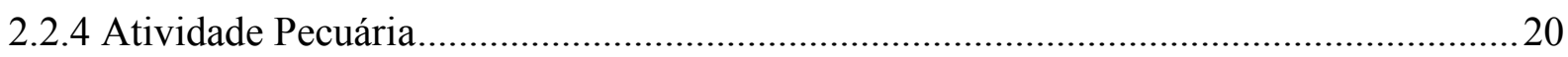

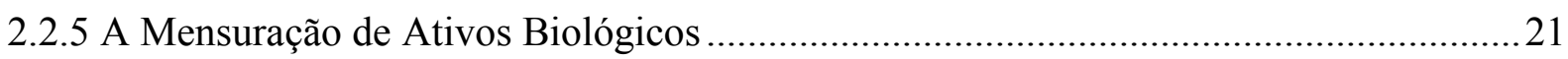

2.3 Abordagem da Contabilidade Rural na Formação dos Graduandos da UnB ....................22

2.3.1 Evolução do Ensino da Contabilidade no Brasil ............................................................22

2.3.2 A Oferta de Disciplinas que Abordam a Contabilidade Rural na UnB .........................23

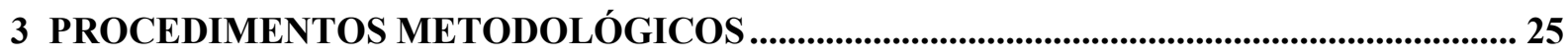

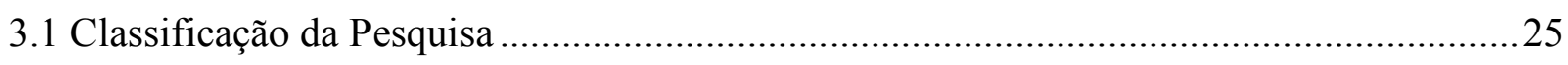

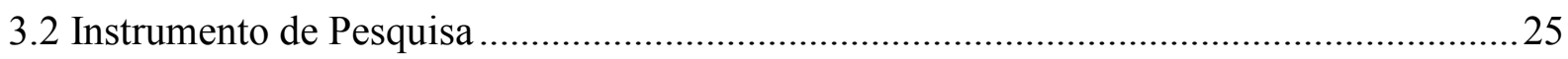

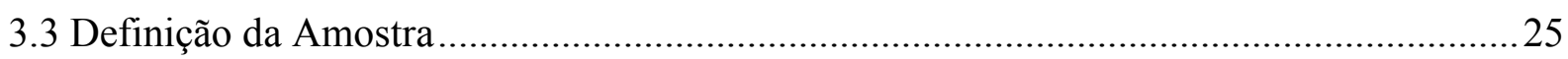

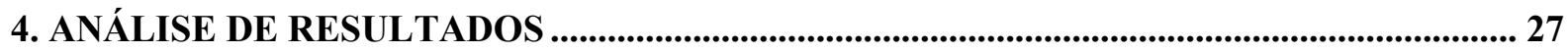

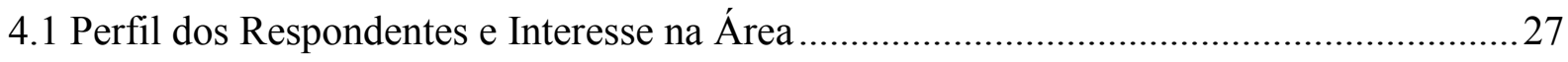

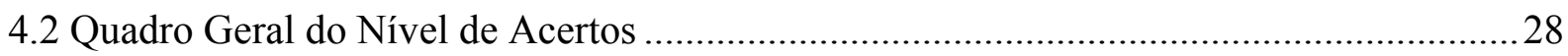

4.3 Nível de Acerto, de Acordo com o Perfil dos Respondentes ............................................ 30

4.4 Nível de Acerto, de Acordo com o Interesse no Assunto................................................ 31

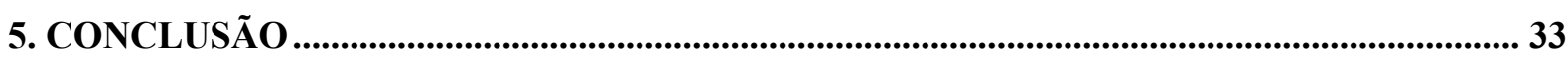

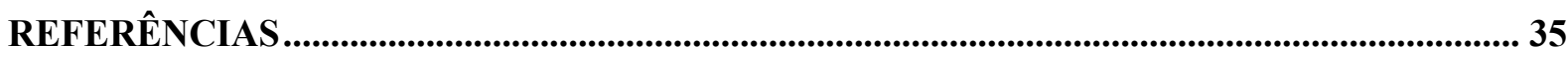




\section{INTRODUÇÃO}

\subsection{Contextualização}

A atividade agropecuária tem relevante importância para a humanidade desde seu surgimento, pois seu domínio possibilitou ao homem abandonar o nomadismo. O avanço tecnológico obtido no século XX possibilitou que a atividade, antes desenvolvida em um contexto familiar e como meio de subsistência se transformasse em uma atividade de larga escala, com tecnologia e conhecimentos intensos envolvendo grandes cooperações e mercados organizados (RECH, 2011).

O avanço da atividade rural e sua importância na economia fez com que a contabilidade se tornasse importante ferramenta para os produtores nas tomadas de decisões, contribuindo para melhorar a organização das propriedades. Assim como acontece nos outros ramos da economia, a contabilidade possibilita um controle eficiente e um bom gerenciamento do agronegócio (PORTAL BLB BRASIL, 2017).

Segundo Ulrich (2009) a contabilidade é reconhecida principalmente por sua capacidade de mensurar e informar de forma objetiva as informações gerenciais para oferecer suporte nas tomadas de decisão, este suporte oferecido é o que possibilita que a contabilidade desempenhe seu papel, independente do ramo que esteja estudando. Crepaldi (2007) define contabilidade como a ciência que estuda e controla o patrimônio das entidades, por meio da demonstração expositiva e interpretação dos fatos ocorridos. Segundo Iudícibus (2010), o objetivo da Contabilidade é fornecer aos usuários em geral informações sobre o patrimônio de uma entidade e suas mutações.

A contabilidade, com o intuito de estudar especificamente cada setor, se ramifica em setores como: industrial, hospitalar, agrícola, etc. Ulrich (2009, p.5) afirma que "a contabilidade rural se destaca como o principal instrumento de apoio às tomadas de decisões durante a execução e o controle das operações da empresa rural”. Segundo Calderelli (2003), a Contabilidade Rural é "aquela que tem suas normas baseadas na orientação, controle e registro dos atos e fatos ocorridos e praticados por uma empresa cujo objeto de comércio ou indústria seja agricultura ou pecuária".

A maneira como a contabilidade manipula as informações referentes as receitas, despesas, custos e ganhos incorridos na Contabilidade Rural é impactado pelas particularidades apresentadas pelo setor, como a sazonalidade no plantio, a produção geralmente é perecível, a influência do clima, além da diversidade de cada item que exige tratamentos diferenciados. 


\subsection{Problema}

Libonati (1996) afirma que o Brasil é um dos maiores produtores mundiais de uma série de produtos agrícolas. O cenário apresentado por ele se manteve na agricultura e se expandiu para a pecuária. Segundo o Instituto Brasileiro de Geografia e Estatística (IBGE, 2016), atualmente o país é o maior exportador de carne bovina no mundo, contando em 2016 com um rebanho de 215 milhões de cabeça de gado. Neste contexto, as projeções apresentadas pela Organização para a Cooperação e Desenvolvimento da Europa (OCDE) e da Organização das Nações Unidas para Agricultura e Alimentação (FAO) é de que o Brasil assumirá a liderança das exportações mundiais do setor agrícola em 2024 (G1, 2015).

Levando em consideração os fatos que reiteram a importância do setor do agronegócio para a economia brasileira e a forma como o tema tem sido abordado no meio acadêmico, baseado no estudo desenvolvido por Costa, Libonati e Rodrigues (2004), este trabalho visa responder: Qual o domínio e a percepção dos graduandos em Ciências Contábeis da Universidade de Brasília (UnB) sobre Contabilidade Rural?

\subsection{Objetivo}

Tendo em vista o problema de pesquisa levantado, o objetivo geral desta pesquisa é identificar o conhecimento dos graduandos em ciências contábeis da UnB sobre especificidades da Contabilidade Rural.

\subsection{Justificativa}

O Distrito Federal, apesar de apresentar economia voltada ao serviço público, apresenta uma gama diversificada de produtores rurais e está rodeado de estados que são grandes produtores do agronegócio brasileiro, como Goiás, Minas Gerais, Mato Grosso e Mato Grosso do Sul, que necessitam de profissionais preparados para lhes prestar serviços.

O estudo desenvolvido por Costa, Libonati e Rodrigues (2004) verificou se os contadores que estão em exercício em Recife conhecem as particularidades atreladas a Contabilidade Rural e constatou que as duas principais instituições de ensino da cidade não ministravam, na época, nenhuma disciplina que abordasse o assunto.

Rech (2011) afirma que a falta de critérios homogêneos para a mensuração das características comuns a todos ativos do agronegócio e a importância do setor, demonstram a 
necessidade de mais estudos sobre o assunto. Pretendendo estimular o debate sobre a formação profissional contábil e uma reflexão sobre a necessidade de alguma abordagem do tema nas grades curriculares das universidades, foi aplicado uma adaptação do questionário utilizado nesta pesquisa entre os graduandos de Ciências Contábeis da Universidade de Brasília. É então uma oportunidade de complementar e enfatizar a amplitude do ensino sobre Contabilidade Rural na UnB. 


\section{REFERENCIAL TEÓRICO}

2.1 A importância do Agronegócio na Economia Brasileira

O Brasil apresenta grande potencial para a agricultura devido à sua dimensão territorial, clima, matriz energética além de contar, aproximadamente, com 13\% da água doce renovável do mundo. Mesmo apresentando tantos fatores favoráveis, o país continua apresentando condições para desenvolver seu potencial produtivo para a agricultura (Rocha; ET. AL, 2013).

O IBGE (2017) demonstrou que no primeiro trimestre de 2017 o Produto Interno Bruto (PIB) cresceu 1,0\% em relação ao último trimestre de 2016, a primeira alta após oito trimestres consecutivos de queda. Enquanto a Agropecuária apresentou no mesmo período crescimento avaliado em $13,40 \%$, a indústria cresceu $0,9 \%$ e os serviços $0,0 \%$ nesse período, o que demonstra estatisticamente que a agropecuária apresenta crescimento percentual superior ao registrado pela economia brasileira. Esse resultado foi obtido levando em consideração a queda das exportações relacionadas a pecuária em 2016, causadas principalmente pelas irregularidades apresentadas em alguns frigoríficos.

O Brasil exporta mais de 150 itens, porém mais de 50\% do valor exportado está concentrado em soja, carnes, açúcar, café, laranja e tabaco, ou seja, em produtos agropecuários. A explicação para este desempenho do setor no comércio exterior é o ganho de competitividade das commodities brasileiras decorrente de melhores condições de qualidade e preço em relação aos outros países. A qualidade melhorou graças ao compromisso em atender as exigências internacionais pelos exportadores e a constante fiscalização do Ministério da Agricultura enquanto os preços são resultado de pesquisas e desenvolvimento obtidos pela Empresa Brasileira de Pesquisa Agropecuária (SILVA; CESÁRIO; CAVALCANTI, 2006).

A Tabela 1 apresenta a evolução da balança comercial brasileira e da balança comercial do agronegócio de 1997 a 2016, realizando um acompanhamento da participação do agronegócio na balança brasileira ao longo deste período. 
Tabela 1: Balança Comercial Brasileira e Balança Comercial do Agronegócio: 1997 a 2016

\begin{tabular}{|c|c|c|c|c|c|c|c|c|}
\hline \multirow[b]{2}{*}{ Ano } & \multicolumn{3}{|c|}{ Exportações } & \multicolumn{3}{|c|}{ Importações } & \multicolumn{2}{|r|}{$\begin{array}{l}\text { US\$ bilhões } \\
\text { Saldo }\end{array}$} \\
\hline & $\begin{array}{c}\text { Total } \\
\text { Brasil } \\
\text { (A) }\end{array}$ & $\begin{array}{l}\text { Agronegócio } \\
\text { (B) }\end{array}$ & $\begin{array}{c}\text { Part.\% } \\
\text { (B/A) }\end{array}$ & $\begin{array}{c}\text { Total } \\
\text { Brasil } \\
\text { (C) }\end{array}$ & $\begin{array}{l}\text { Agronegócio } \\
\text { (D) }\end{array}$ & $\begin{array}{c}\text { Part.\% } \\
\text { (D/C) }\end{array}$ & $\begin{array}{c}\text { Total } \\
\text { Brasil }\end{array}$ & Agronegócio \\
\hline 1997 & 52,98 & 23,37 & 44,1 & 59,75 & 8,20 & 13,7 & $-6,76$ & 15,17 \\
\hline 1998 & 51,14 & 21,56 & 42,1 & 57,76 & 8,04 & 13,9 & $-6,62$ & 13,51 \\
\hline 1999 & 48,01 & 20,50 & 42,7 & 49,30 & 5,70 & 11,6 & $-1,29$ & 14,80 \\
\hline 2000 & 55,12 & 20,60 & 37,4 & 55,85 & 5,76 & 10,3 & $-0,73$ & 14,85 \\
\hline 2001 & 58,29 & 23,87 & 40,9 & 55,60 & 4,81 & 8,6 & 2,68 & 19,06 \\
\hline 2002 & 60,44 & 24,85 & 41,1 & 47,24 & 4,45 & 9,4 & 13,20 & 20,39 \\
\hline 2003 & 73,20 & 30,65 & 41,9 & 48,33 & 4,75 & 9,8 & 24,88 & 25,90 \\
\hline 2004 & 96,68 & 39,04 & 40,4 & 62,84 & 4,84 & 7,7 & 33,84 & 34,20 \\
\hline 2005 & 118,53 & 43,62 & 36,8 & 73,60 & 5,11 & 6,9 & 44,93 & 38,51 \\
\hline 2006 & 137,81 & 49,47 & 35,9 & 91,35 & 6,70 & 7,3 & 46,46 & 42,77 \\
\hline 2007 & 160,65 & 58,43 & 36,4 & 120,62 & 8,73 & 7,2 & 40,03 & 49,70 \\
\hline 2008 & 197,94 & 71,84 & 36,3 & 172,98 & 11,88 & 6,9 & 24,96 & 59,96 \\
\hline 2009 & 152,99 & 64,79 & 42,3 & 127,72 & 9,90 & 7,8 & 25,27 & 54,89 \\
\hline 2010 & 201,92 & 76,44 & 37,9 & 181,77 & 13,40 & 7,4 & 20,15 & 63,04 \\
\hline 2011 & 256,04 & 94,97 & 37,1 & 226,25 & 17,51 & 7,7 & 29,79 & 77,46 \\
\hline 2012 & 242,58 & 95,81 & 39,5 & 223,18 & 16,41 & 7,4 & 19,39 & 79,41 \\
\hline 2013 & 242,03 & 99,97 & 41,3 & 239,75 & 17,06 & 7,1 & 2,29 & 82,91 \\
\hline 2014 & 225,10 & 96,75 & 43,0 & 229,15 & 16,61 & 7,3 & $-4,05$ & 80,13 \\
\hline 2015 & 191,13 & 88,22 & 46,2 & 171,45 & 13,07 & 7,6 & 19,69 & 75,15 \\
\hline 2016 & 185,24 & 84,93 & 45,9 & 137,55 & 13,63 & 9,9 & 47,68 & 71,31 \\
\hline
\end{tabular}

Fonte: Agrostat Brasil a partir de dados da SECEX/MDIC, 2017

Elaboração: DAC / SRI / MAPA

Conforme Tabela 1, 45,9\% das exportações do país em 2016 se referem ao agronegócio. É possível observar que desde 1997 a participação deste setor nas exportações realizadas no país representou porcentagem superior a 35\%. Em relação às importações, em 2016 o agronegócio representou $9,9 \%$ das transações realizadas no país, e historicamente valores inferiores a $14 \%$ do total. Isso demonstra que o agronegócio contribui positivamente na balança comercial brasileira ao longo dos anos.

O agronegócio apresentou superávit de US\$ 7,1 bilhões em abril de 2016, enquanto outros setores apresentaram déficit de US\$2,2 bilhões. O setor de carnes apresentou, no mesmo 
período, 4,4\% de aumento em relação ao ano anterior, só em carnes de frango o aumento foi de 9,7\% (PORTAL BRASIL, 2016).

O agronegócio tem sido um dos responsáveis pelo desempenho positivo da economia do país, enquanto outros setores se mantêm constantes ou em queda, as estimativas do governo para o setor são de crescimento a longo prazo. A atividade rural tem relevância inquestionável na economia brasileira, é responsável por um terço de tudo que o país gera e de grande parcela de todos os produtos que são exportados.

\subsection{Particularidades da Contabilidade Rural}

A empresa rural é uma unidade de produção na qual são exercidas as atividades relativas a culturas agrícolas, pecuária ou culturas florestais, com a finalidade de obtenção de renda (CREPALDI, 2011). Para Gimenes e Gimenes (2007), seja essa empresa familiar ou patronal, independentemente de seu tamanho, ela faz parte do sistema do agronegócio, fato que faz com que o empresário precise de meios para identificar e controlar variáveis que possibilite uma gestão mais eficiente de seu negócio.

O agronegócio não apresenta características homogêneas, dificultando o estabelecimento de métodos para análise da produção. Ela sofre forte interferência de agentes biológicos e outras particularidades que refletem diretamente no tratamento contábil das mesmas. Nesse particular, há uma série de especificidades que transformam a Contabilidade Rural em algo singular, se comparada a outros ramos, particularidades essas destacadas nos tópicos seguintes;

\subsubsection{Exercício Social}

O exercício social é o período em que a empresa deve elaborar as demonstrações contábeis. A Lei $n^{\circ}$ 6.404, de 15 de dezembro de 1976, definiu que o exercício social terá duração de 1(um) ano, porém não ficou fixada a data para início ou término do exercício, este pode ou não coincidir com o ano civil - geralmente é utilizado o período corresponde ao ano civil, de 01 de janeiro à 31 de dezembro, principalmente pela facilidade de controle. Porém, como a atividade rural apresenta sazonalidade, é permitido que sejam apresentadas as demonstrações contábeis durante a época em que o patrimônio e resultados estejam melhores representados.

Conforme apresentado por Costa, Libonati e Rodrigues (2004), o ano agrícola corresponde ao período do início do cultivo até o momento da colheita, já que é após a colheita ou durante ela que ocorre uma concentração de receitas. 
Marion (2014) orienta que para produtores de culturas diversificadas seja utilizado como exercício social o ano agrícola correspondente à cultura de maior representatividade econômica e que o mesmo raciocínio seja utilizado para diversas culturas, mesmo que não estejam conjugadas, enquanto na pecuária o fim do exercício social deve coincidir com a data do nascimento dos rebanhos, já que o bezerro será o produto final que valoriza o patrimônio da empresa.

\subsubsection{Culturas Agrícolas}

Existem dois tipos de culturas agrícolas: as temporárias e as permanentes. As culturas temporárias são as que têm um período de vida curto, não superior a um ano, o que as torna conhecidas como culturas anuais, necessitando de replantio após a colheita. Como exemplo, podem ser citadas as culturas da soja e do arroz, que durante a colheita são arrancadas do solo. Por outro lado, as culturas permanentes têm um período de vida superior a um ano, estão vinculadas ao solo e proporcionam mais de uma colheita, sendo consideradas como fatores de produção por diversos anos. É o caso da maçã e da goiaba, que por serem frutas arbóreas têm apenas o fruto arrancado na colheita, com a árvore permanecendo atrelada ao solo após este período (MAPA, 2008).

Marion (2014) considera "Custo de Cultura" todos os gastos identificáveis com a cultura, direta ou indiretamente, citando exemplos como sementes, adubos e depreciação de equipamentos, enquanto "Despesas do Período" seriam os gastos não identificáveis com a cultura, não sendo acumulados em estoque, são elas as despesas administrativas, financeiras, etc. Porém, orienta-se que todo custo com a colheita seja acumulado em uma conta denominada "Cultura Temporária" e após seu término, seja baixada e transferida para a conta "Produtos Agrícolas", onde também serão registrados todos os gastos posteriores à colheita. Desta forma, após a venda da produção, é baixado proporcionalmente os valores de produtos agrícolas e transferidos para "Custo do Produto Vendido".

Já nas culturas permanentes os custos incorridos antes da colheita são alocados em uma conta pertencente ao ativo permanente, junto com os imobilizados em uma conta denominada “Cultura Permanente em Formação”, que após a primeira colheita é transferida para a conta "Cultura Permanente Formada". Durante a fase em que esta cultura está produtiva, todos os outros custos serão alocados no ativo circulante, dentro de estoques na conta "Colheita em Andamento" (MARION, 2014). 


\subsubsection{Amortização, Depreciação e Exaustão}

A amortização é a alocação sistemática do valor amortizável de um ativo intangível ao longo de sua vida útil (CPC 04). Depreciação é a alocação sistemática do valor depreciável de um ativo ao longo de sua vida útil (CPC 27). Exaustão é a redução do valor de investimentos necessários à exploração de recursos minerais ou florestais. A medida que os recursos minerais vão se exaurindo, registra-se na contabilidade, simetricamente conhecida como jazida, a quota de exaustão (FERREIRA, 2015).

Segundo Marion (2014), na Contabilidade Rural a depreciação é aplicada sobre as culturas permanentes, em florestas, árvores, ou vegetais dos quais são extraídos apenas os frutos. Ela também deve ser aplicada sobre o maquinário agrícola, tratores e colhedeiras, onde a depreciação deve ser calculada por hora, pois a apropriação ocorre de acordo com o uso nas safras (COSTA; LIBONATI; RODRIGUES, 2004).

A exaustão ocorreria na extração do solo ou no corte da árvore, sendo utilizada nas safras da cana-de-açúcar e pastagens que são destinadas ao corte. Segundo Costa, Libonati e Rodrigues (2004), tanto para depreciação, quanto para exaustão, o período é determinado em função da vida útil da produção ou da população total estimada, onde só será possível definir a taxa, com a colaboração de um agricultor ou agrônomo.

Segundo Marion (2014), a amortização ocorre em direitos sobre empreendimentos de propriedades de terceiros. Como exemplo, a aquisição de direitos de extração de madeira de floresta pertencente a terceiros.

\subsubsection{Atividade Pecuária}

A pecuária está relacionada à criação de gado em geral, sejam bois, vacas, carneiros, aves, ovelhas, entre outros. Existem alguns tipos de atividade pecuária como a cria, que consiste na criação de bezerros que só serão vendidos após o desmame; a recria que é a partir do bezerro desmamado, a produção e venda do novilho magro para engorda; a engorda onde a partir do novilho magro há a produção do novilho gordo para comercialização do próprio animal ou de seus derivados (COSTA; LIBONATI; RODRIGUES, 2004).

Marion (2014) orienta que os custos dos animais destinados à engorda devem ser destinados ao estoque no ativo circulante, enquanto os custos destinados à reprodução dos animais ou à produção de seus derivados devem ser imputados ao Imobilizado. Enquanto o gado, que encontra-se em crescimento, deve ser classificado como ativo circulante em estoques, até que apresente características para reprodução, quando devem ser transferidos para o ativo permanente no imobilizado. 
Segundo Marion (2014), para elaboração da depreciação, será necessária a colaboração de um veterinário para determinar a vida útil de um gado reprodutor, de maneira que a depreciação comece a partir do declínio do animal. Porém, como identificar esse ponto é difícil, é possível depreciar a partir do momento em que o rebanho é utilizado para reprodução.

Costa, Libonati e Rodrigues (2004) criticam o uso de custo histórico na pecuária, pois a variação patrimonial é intensa, já que deve levar em consideração o crescimento natural do gado. O ativo é acrescido de valor econômico real, tornando os custos históricos inadequados.

\subsubsection{A Mensuração de Ativos Biológicos}

Em 2009 surgiu a primeira norma contábil, específica para o setor agropecuário, à International Accounting Standard (IAS) 41, que estabeleceu que os ativos biológicos passassem a ser mensurados pelo valor justo, já que a falta de normatização fazia com que as entidades incorporassem os ganhos patrimoniais associados a estes ativos apenas no momento da venda, utilizando o custo histórico como base para sua mensuração. Apesar de ser mais subjetiva e volátil, a mensuração pelo valor justo, reflete melhor as alterações econômicas das empresas, já que a mensuração pelo custo histórico evidencia o ganho destes ativos apenas no momento da venda (MACIEL; BOTELHO, 2016).

O Custo histórico representa o registro dos ativos por seus valores de aquisição. Segundo Silva, Martins e Machado (2013), ativos biológicos, quando avaliados pelo custo histórico, tendem a apresentar valores subestimados pela contabilidade, de forma que a avaliação pelo valor presente foi benéfica já que apresenta valor do ativo mais próximo à estimação do mercado. O custo histórico, por se limitar aos valores referentes à data da aquisição ou produção dos bens, pode não refletir a capacidade de benefício econômico apresentado pelo bem.

O valor justo é definido pelo CPC 46, como o preço que seria recebido pela venda de um ativo, ou que seria pago pela transferência de um passivo em uma transação não forçada na data da mensuração. Ou seja, valor justo é o valor em que no momento do fechamento do balanço, a entidade obteria com a comercialização do bem em questão.

O CPC 29, correlato à IAS 41, que aborda o tratamento contábil dos ativos biológicos e produtos agrícolas afirma que ativos biológicos devem ser mensurados pelo valor justo e não pelo custo histórico, como era praticado anteriormente. O CPC define ativo biológico como animais ou plantas vivas, desde o nascimento ou plantio, até o ponto de abate ou colheita. A mensuração citada se daria em três níveis, a realizada a partir de preços listados em um mercado ativo para um bem idêntico ao que será vendido, o valor que deve ser adotado quando existir 
um mercado ativo de bens semelhantes e o último onde é necessário o uso de técnicas de avaliação para descoberta do valor.

O ativo biológico deve ser reconhecido apenas quando for possível provar a geração de benefícios econômicos futuros associados a ele, devendo ser mensurados a valor justo, diminuídas as despesas de vendas, no início e fim de cada período de venda (MACIEL e BOTELHO, 2016).

\subsection{Abordagem da Contabilidade Rural na Formação dos Graduandos da UnB}

A contabilidade do agronegócio deve ser abordada nos cursos de contabilidade do país, principalmente pela importância que o setor tem na economia brasileira. Porém, é interessante observar quais tópicos são ministrados nas disciplinas que englobam o tema, possibilitando analisar quais delas os departamentos acadêmicos consideram mais relevantes.

\subsubsection{Evolução do Ensino da Contabilidade no Brasil}

Em 1808, ao se tornar sede do império português ocorreram diversas mudanças no Brasil, entre elas o governo passou a se preocupar com negócios públicos e privados desenvolvidos. Consequência disso foi a criação de uma cadeira de Aula Pública de Ciências Econômicas no Rio de Janeiro, o curso apresentava duração de 2 anos e o currículo incluía disciplinas voltadas as necessidades diárias dos negócios, com instrumentos de gestão mais precisos, existentes na contabilidade (PELEIAS; ET AL, 2007).

Segundo Peleias et al. (2007), na segunda metade do século XIX ocorreu a reforma da Aula de Comércio, que se transformou em Instituto Comercial do Rio de Janeiro. Apesar de manter a duração de 2 anos, o conteúdo do curso foi dividido em quadro cadeiras, sendo a primeira Contabilidade e Escrituração Mercantil. A partir da criação do Instituto, as disciplinas ministradas foram se adaptando ao modelo de comércio desenvolvido na época.

A partir da Proclamação da República, ocorreram grandes mudanças no modelo de comércio brasileiro. O Instituto Comercial do Rio de Janeiro foi substituído pela Academia de Comércio do Rio de Janeiro que contava com dois cursos, um com uma formação prática, que abordava disciplinas para uma formação geral em comercio, e outro superior, que além da formação voltada para o comercio oferecia disciplinas específicas sobre Contabilidade do Estado e Contabilidade Mercantil Comparada (PELEIAS; ET. AL, 2007).

Furtado (1995) relata que a crise cafeeira ocorrida no século XX fez com que o país passasse por um período de inflexão da matriz produtiva, o que exigiu modernização de serviços 
e especialização da mão de obra. Foram criadas a partir daí outras escolas no país voltadas para o comércio, com os cursos passando a compreender entre 3 e 4 anos, conferindo aos estudantes o diploma de Contador. Foram incluídas disciplinas de Contabilidade Agrícola e Industrial, Contabilidade Pública e Mercantil. Em 1945, por meio do Decreto-lei n n $^{\text {7.988, de }} 22$ de setembro de 1945, foi criado o curso de Ciências Contábeis, com duração de quatro anos e disciplinas como a de Contabilidade Geral, Industrial, Agrária, Pública, e Perícia Contábil.

A partir o histórico apresentado acima é possível observar que a Contabilidade Agrária compõe o currículo da graduação em ciências contábeis desde sua criação. Atualmente o assunto ocupa espaço menos relevante na grade curricular, porém este fato não implica em perda de importância do tema para formação de bons profissionais.

\subsubsection{A Oferta de Disciplinas que Abordam a Contabilidade Rural na UnB}

A partir de uma análise das disciplinas ofertadas pelo Departamento de Ciências Contábeis e Atuariais da UnB que abordam o tema. Para isso foram verificadas as ementas de todas as matérias vinculadas ao Departamento nos últimos 12 semestres, do $1^{\circ}$ semestre de 2012 ao $2^{\circ}$ semestre de 2017. Foram segregadas todas disciplinas que continham citação específica em sua ementa acerca dos conteúdos inerentes a contabilidade do agronegócio e verificada a bibliografia recomendada.

De acordo com o material disponibilizado pelo Departamento, no segundo semestre de 2017 foram ofertadas 39 disciplinas. Dessas, 5 não apresentaram ementa e 33 não abordam o assunto. Levando em consideração somente a ementa, apenas uma disciplina ofertada no semestre analisado aborda o tema.

A disciplina se intitula Contabilidade Agrária, que apresenta toda ementa voltada para aspectos da Contabilidade Rural como: análise e compreensão da atividade rural, fluxo contábil na atividade agrícola, ativos biológicos, depreciação na agropecuária, planificação contábil na atividade agrícola, contabilidade da pecuária, custos na pecuária, cálculo do custo do bezerro, imposto de renda e o fluxo de caixa no setor rural. Além do $2^{\circ}$ semestre de 2017 , durante o período analisado, ela foi ofertada anteriormente apenas no $1^{\circ}$ semestre de 2015.

O Quadro 1 apresenta os tópicos abordados na disciplina Contabilidade Rural ministrada na UnB e foi elaborado a partir da ementa da disciplina disponibilizada no Matricula Web.

Quadro 1: Tópicos abordados na disciplina Contabilidade Agrária, no $2^{\circ}$ semestre de 2017

\begin{tabular}{|l|l|}
\hline Tópico & Desenvolvimento do tópico segundo programa disponibilizado \\
\hline Atividade Rural & $\begin{array}{l}\text { Empresas Rurais. Contabilidade rural. Ano agrícola x exercício social. Forma } \\
\text { jurídica de exploração na agropecuária. Ativos biológicos e produto agrícola. }\end{array}$ \\
\hline
\end{tabular}




\begin{tabular}{|c|c|}
\hline $\begin{array}{l}\text { Fluxo contábil } \\
\text { atividade agrícola }\end{array}$ & $\begin{array}{l}\text { Culturas temporárias. Culturas permanentes. Alguns comentários sobre cultura } \\
\text { permanente. }\end{array}$ \\
\hline Ativos biológicos & $\begin{array}{l}\text { Introdução. Métodos de avaliação de ativos. Cultura temporária considerando o valor } \\
\text { justo. Culturas permanentes a valor justo. Estimando valor justo dos ativos biológicos } \\
\text { de uma cultura permanente quando não há mercado ativo. }\end{array}$ \\
\hline $\begin{array}{l}\text { Depreciação } \\
\text { agropecuária }\end{array}$ & $\begin{array}{l}\text { Conceitos conforme a teoria da contabilidade. Entendimento fiscal na agropecuária. } \\
\text { Casos de depreciação. Casos de exaustão. Amortização. Taxas de depreciação. }\end{array}$ \\
\hline $\begin{array}{l}\text { Planificação contábil } \\
\text { na atividade agrícola }\end{array}$ & $\begin{array}{l}\text { Resumo dos principais itens que compõem o balanço patrimonial e a demonstração } \\
\text { do resultado do exercício de uma empresa industrial. Adequação de alguns itens para } \\
\text { empresas agrícolas. Operacionalização do plano de contas. Sistema auxiliar de } \\
\text { contas. }\end{array}$ \\
\hline $\begin{array}{l}\text { Contabilidade } \\
\text { pecuária }\end{array}$ & $\begin{array}{l}\text { Tipos de atividade pecuária. Classificação do gado no balanço patrimonial. Curto e } \\
\text { longo prazos na pecuária. Plano de contas. Sistema auxiliar de conta. Variação } \\
\text { patrimonial líquida. Método de custo x método a valor de mercado. Nascimento do } \\
\text { bezerro. }\end{array}$ \\
\hline $\begin{array}{l}\text { Contabilidade } \\
\text { pecuária }\end{array}$ & ica para utilização do custo histórico na pecuária. Ativos biológicos. \\
\hline Custos na pecuária & $\begin{array}{l}\text { Críticas ao custo histórico utilizado na pecuária. Exceções ao custo histórico aceitas. } \\
\text { Uma proposição de contabilidade na pecuária. Uma proposição de contabilidade de } \\
\text { custos na pecuária. }\end{array}$ \\
\hline $\begin{array}{l}\text { Contabilidade da } \\
\text { pecuária - método de } \\
\text { avaliação pelo preço de } \\
\text { mercado }\end{array}$ & $\begin{array}{l}\text { Princípio da realização da receita e da confrontação da despesa. Reconhecimento da } \\
\text { receita na pecuária. Reconhecimento da receita na pecuária e repercussão na } \\
\text { distribuição de dividendos e no imposto de renda. Momento da avaliação. } \\
\text { Confrontação da despesa. }\end{array}$ \\
\hline $\begin{array}{l}\text { Cálculo do custo do } \\
\text { bezerro }\end{array}$ & $\begin{array}{l}\text { Custo médio do rebanho. Custo médio dos reprodutores. Custo específico. Custo } \\
\text { corrigido considerando bezerros a nascer. }\end{array}$ \\
\hline Bibliografia & $\begin{array}{l}\text { MARION, José C. Contabilidade Rural: contabilidade agrícola, contabilidade da } \\
\text { pecuária. } 14^{\circ} \text { edição. São Paulo: Atlas, } 2014 \text { e os Pronunciamentos Técnicos CPC. } \\
\text { E apresenta como bibliografia complementar: } \\
\text { MARION, José C.; SEGATTI, Sonia. Contabilidade da Pecuária. } 10^{\circ} \text { edição. São } \\
\text { Paulo: Atlas, 2012; } \\
\text { CREPALDI, Silvio Aparecido. Contabilidade Rural: uma abordagem decisorial. } \\
7^{\circ} \text { edição. São Paulo: Atlas, 2012. } \\
\text { RODRIGUES, Aldenir O.; BUSCH, Cleber M.; GARCIA, Edino R.; TODA, Wiliam } \\
\text { H. Contabilidade Rural. } 2^{\circ} \text { edição. São Paulo: IOB, 2012. }\end{array}$ \\
\hline
\end{tabular}

Fonte: Elaboração Própria 


\section{PROCEDIMENTOS METODOLÓGICOS}

\subsection{Classificação da Pesquisa}

Gil (2008) classifica as pesquisas quanto aos procedimentos técnicos e quanto aos objetivos. Quanto aos procedimentos técnicos, foi realizada uma pesquisa bibliográfica de forma que possibilite discorrer sobre as principais particularidades da Contabilidade Rural, discutidas em trabalhos anteriores disponíveis em periódicos de contabilidade, dissertações e livros. Segundo Gil (2008) pesquisa bibliográfica é aquela desenvolvida a partir de material já elaborado, constituído principalmente de livros e artigos científicos. Com o intuito de responder o questionamento apresentado neste trabalho foi realizada ainda uma pesquisa de campo. Segundo Gil (2008) os estudos de campo se caracterizam pelo aprofundamento das questões propostas, onde estuda-se um único grupo ou comunidade ressaltando a interação de seus componentes

\subsection{Instrumento de Pesquisa}

Foi utilizada como instrumento de pesquisa uma adaptação do questionário utilizado por Costa, Libonati e Rodrigues (2004), aplicado pessoalmente nas salas de aula do campus Darcy Ribeiro na UnB e de forma eletrônica, via formulário no Google Drive.

O questionário continha 15 questões, a primeira pergunta tem o intuito de segregar os alunos do último ano da graduação dos demais alunos, enquanto as questões 2, 3 e 4 tinha o intuito de verificar se o aluno já teve contato com a disciplina durante a graduação. As questões de 5 a 13 objetivam testar o conhecimento do estudante sobre Contabilidade Rural, enquanto as questões 14 e 15 têm como propósito verificar a opinião do aluno quanto à importância em se estudar o assunto em pauta.

Os questionários foram aplicados durante a segunda quinzena de novembro de 2017, antes do fim do semestre letivo.

\subsection{Definição da Amostra}

Como universo foram escolhidos os alunos da UnB, do curso de Ciências Contábeis e como amostra os 296 alunos que responderam o questionário. Trata-se de amostra não probabilística, definida por conveniência de acesso aos alunos.

Foram aplicados 296 questionários, dos quais 78 foram respondidos pelo Google Drive e 218 pessoalmente nas salas de disciplinas voltadas para alunos de Ciências Contábeis. Durante a aplicação os alunos receberam algumas instruções como: o questionário só pode ser 
respondido por graduandos em Ciências Contábeis; nas questões em que o respondente não souber a resposta deve-se utilizar o conhecimento obtido até o momento na graduação e assinalar a alternativa que mais lhe parecer correta e questionários em que houver alguma questão em branco serão desconsiderados. 


\section{ANÁLISE DE RESULTADOS}

A análise dos resultados será realizada a partir da comparação do perfil dos respondentes e o interesse apresentado na área com nível de acerto apresentado no questionário.

\subsection{Perfil dos Respondentes e Interesse na Área}

O primeiro tópico de análise se concentra no perfil dos respondentes, bem como no interesse demonstrado por esses na área pesquisa - Contabilidade Rural. São utilizadas, para esse fim, as respostas às questões 1 a 4, 14 e 15 do instrumento de pesquisa aplicado. Os resultados são consolidados na Tabela 2.

Tabela 2: Perfil dos respondentes e interesse na área

\begin{tabular}{|c|c|c|c|c|c|c|}
\hline \multirow{2}{*}{ Questão } & \multicolumn{2}{|c|}{ Sim } & \multicolumn{2}{|c|}{ Não } & \multicolumn{2}{|c|}{$\begin{array}{c}\text { Nunca li sobre o } \\
\text { assunto }\end{array}$} \\
\hline & Qtd & $\%$ & Qtd & $\%$ & Qtd & $\%$ \\
\hline $\begin{array}{l}\text { Q1. Você está cursando o último ano } \\
\text { da graduação? }\end{array}$ & 90 & $30,41 \%$ & 206 & $69,59 \%$ & - & - \\
\hline $\begin{array}{l}\text { Q2. Já cursou alguma disciplina de } \\
\text { Contabilidade Rural ou correlata? }\end{array}$ & 33 & $11,15 \%$ & 263 & $88,85 \%$ & - & - \\
\hline $\begin{array}{l}\text { Q3. Já assistiu alguma palestra } \\
\text { seminário ou mesmo leu sobre } \\
\text { Contabilidade Rural? }\end{array}$ & 47 & $15,88 \%$ & 249 & $84,12 \%$ & - & - \\
\hline $\begin{array}{l}\text { Q4. A literatura existente sobre } \\
\text { Contabilidade Rural aborda o assunto } \\
\text { de forma objetiva e clara? }\end{array}$ & 24 & $8,11 \%$ & 24 & $8,11 \%$ & 248 & $83,78 \%$ \\
\hline $\begin{array}{l}\text { Q14. Na sua opinião, nas grades } \\
\text { curriculares dos cursos de Ciências } \\
\text { Contábeis deveria haver a disciplina } \\
\text { de Contabilidade Rural? }\end{array}$ & 213 & $71,96 \%$ & 83 & $28,04 \%$ & - & - \\
\hline $\begin{array}{l}\text { Q15. Você faria uma pós-graduação } \\
\text { ou um curso de extensão na área? }\end{array}$ & 102 & $34,46 \%$ & 194 & $65,54 \%$ & - & - \\
\hline
\end{tabular}

Fonte: Elaboração Própria

De forma geral, o perfil dos respondentes revela que: $30 \%$ dos alunos já estão cursando o último ano da graduação; apenas $11 \%$ cursaram alguma disciplina de Contabilidade Rural ou correlata; menos de $16 \%$ assistiram alguma palestra ou seminário sobre o tema; e quase $84 \%$ dos respondentes nunca leram sobre o assunto.

Esse resumo demonstra que o grau de conhecimento sobre Contabilidade Rural pode ser considerado como baixo, pelo menos em termos de disciplinas formais, palestras ou seminários. Isso pode ser decorrente de fatores como a sazonalidade apresentada na oferta das disciplinas pela universidade e por não haver disponível eventos acadêmicos que abordem este assunto. 
Em relação ao grau de interesse dos respondentes no tema, os resultados demonstram que $72 \%$ dos alunos consideram importante haver uma disciplina de Contabilidade Rural na grade curricular do curso de Ciências Contábeis, porém mais de $65 \%$ dos graduandos não fariam uma pós-graduação ou extensão no assunto. Em resumo, apesar de considerarem importante haver a disciplina para abordagem do assunto durante a graduação, não se interessam em estudar o assunto de forma mais profunda.

\subsection{Quadro Geral do Nível de Acertos}

O segundo tópico de análise dos resultados consiste em avaliar o nível geral de acertos às questões elaboradas para testar o conhecimento dos alunos sobre particularidades da Contabilidade Rural. Esse quadro geral está consolidado na Tabela 3.

Tabela 3: Nível geral de acerto

\begin{tabular}{|c|c|c|c|c|}
\hline \multirow{2}{*}{ Questão } & \multicolumn{2}{|c|}{ Acertos } & \multicolumn{2}{|c|}{ Erros } \\
\hline & Qtd & $\%$ & Qtd & $\%$ \\
\hline $\begin{array}{l}\text { Q5. Numa atividade agrícola com diversas culturas em } \\
\text { períodos de colheitas diferentes, prevalece ano agrícola com } \\
\text { base em: }\end{array}$ & 156 & $52,70 \%$ & 113 & $47,30 \%$ \\
\hline $\begin{array}{l}\text { Q6. Uma cultura permanente em formação é classificada } \\
\text { como: }\end{array}$ & 82 & $27,70 \%$ & 214 & $72,30 \%$ \\
\hline Q7. A depreciação passa a incidir sobre a cultura: & 129 & $43,58 \%$ & 167 & $56,42 \%$ \\
\hline $\begin{array}{l}\text { Q8. Os gastos com benfeitorias rurais como "Estradas", } \\
\text { "Açudes", "Cercas", "Instalações" e "Bebedouros" devem } \\
\text { ser classificados como: }\end{array}$ & 197 & $66,56 \%$ & 99 & $33,44 \%$ \\
\hline $\begin{array}{l}\text { Q9. Relativo à pecuária, o plantel em crescimento deve ser } \\
\text { classificado no: }\end{array}$ & 88 & $29,73 \%$ & 208 & $70,27 \%$ \\
\hline Q10. Custos históricos na pecuária são considerados: & 175 & $59,12 \%$ & 121 & $40,88 \%$ \\
\hline Q11.Cultura temporária em formação é classificada como: & 116 & $39,19 \%$ & 180 & $60,81 \%$ \\
\hline Q12. As cotas de exaustão podem ser aplicadas em: & 214 & $72,30 \%$ & 82 & $27,70 \%$ \\
\hline Q13. Reprodutores e matrizes são classificados no: & 111 & $37,50 \%$ & 185 & $62,50 \%$ \\
\hline
\end{tabular}

Média geral de Acertos $=47,60 \%$

Fonte: Elaboração Própria

A média geral de acertos foi de $47,60 \%$ do questionário, as questões que apresentaram percentual superior à média foram as 5, 8, 10 e 12. Dentre elas o item 8 foi o único a abordar uma classificação no Balanço Patrimonial apresentando vários exemplos, o que pode ter aumentado a chance de acerto. É possível observar que os assuntos abordados nas questões 10 
e 12 podem ser respondidos utilizando os conhecimento em contabilidade geral, o que pode justificar a porcentagem de acerto superior à média.

As questões que apresentaram percentual de acerto inferior à média foram as 6, 7, 9, 11 e 13, todas, com exceção da 7 , se referem a classificação de elementos da contabilidade rural dentro de um Balanço Patrimonial, exigindo dos alunos conhecimento específico sobre o tema. O item 7 se refere a incidência da depreciação sobre uma cultura, provavelmente por não obterem conhecimento sobre o que é uma cultura, ele se enquadrou neste grupo.

As perguntas que apresentaram maior porcentagem de acerto foram as 12 e 8 . A 12 apresentou percentual de acerto de $72,30 \%$ dos respondentes, por se tratar de cotas de exaustão, um assunto abordado em contabilidade geral, já sendo esperado que o percentual de acerto nesta questão fosse elevado. Já a questão 8 apresentou percentual de acerto de 66,56\%, o que pode ter ocorrido devido aos vários exemplos citados na questão do que deveria ser classificado no balanço, facilitando a associação dos alunos à elementos conhecidos.

Os itens que apresentaram menor porcentagem de acerto foram o 6 e o 9 . A questão 6 apresentou percentual de acerto de $27,70 \%$ e a 9 de $29,73 \%$. As duas solicitara, que o aluno classificassem elementos da contabilidade rural no balanço patrimonial, por não obterem conhecimento sobre a nomenclatura adotada como plantel e cultura, a porcentagem de acerto apresentada foi tão baixa.

A resposta correta para a Questão 5 é que numa cultura agrícola com diversas culturas prevalece o ano agrícola baseado na cultura de maior representatividade e mais da metade dos alunos acertaram esta questão. Apenas $27,70 \%$ dos respondentes acertaram a Questão 6, referente a classificação no balanço de uma cultura permanente em formação, a resposta correta é Ativo Circulante - Imobilizado, esta foi a questão com menor percentual de acerto. A resposta correta da Questão 7 é que a depreciação passa a incidir sobre a cultura a partir da primeira safra e apresentou $43,58 \%$ como percentual de acerto.

Referente aos gastos com benfeitorias e sua classificação no balanço, abordados na Questão 8 mais da metade dos questionários foram respondidas corretamente, 66,56\% assinalaram que estes gastos devem ser incluídos no Ativo Não-Circulante - Imobilizado. A resposta correta, a Questão 9 é Ativo Circulante - Estoques para a classificação de um plantel em crescimento e apenas 29,73\% dos alunos acertaram. Custos históricos na pecuária são considerados inadequados e apresentou como percentual de acerto $59,12 \%$, este tópico foi abordado na Questão 10.

Uma cultura temporária em formação deve ser classificada como Ativo Circulante Estoque, a Questão 11 abordou este assunto e 39,19\% dos respondentes acertaram esta questão. 
É possível responder a Questão 12 sem conhecimentos específicos sobre Contabilidade Rural. As cotas de exaustão podem ser aplicadas em florestas e espécies vegetais destinadas ao corte e $72,30 \%$ dos graduandos responderam corretamente, conforme previsto esta foi a questão com maior porcentagem de acerto, afinal este assunto é abordado na contabilidade geral.

Na pecuária, reprodutores e matrizes são classificados como Ativo Não-Circulante Imobilizado e a Questão 13 que abordou este assunto apresentou porcentagem de acerto de $37,50 \%$.

A porcentagem de acerto das questões em geral foi baixa, o que já era esperado, visto que a maioria nunca teve contato com a tema. Com exceção das questões que podem ser respondidas apenas com os conhecimentos obtidos na Contabilidade Geral o percentual de acerto foi inferior à $50 \%$.

4.3 Nível de Acerto, de Acordo com o Perfil dos Respondentes

O terceiro tópico de análise dos resultados consiste em avaliar o nível geral de acertos das questões elaboradas para testar o conhecimento dos alunos sobre particularidades da Contabilidade Rural com relação ao perfil dos respondentes. Os resultados são apresentados na tabela 4.

Tabela 4: Nível de acerto, de acordo com o perfil dos respondentes

\begin{tabular}{|c|c|c|c|c|c|c|}
\hline \multirow[b]{2}{*}{ Respostas } & \multicolumn{2}{|c|}{$\begin{array}{c}\text { Você está cursando o } \\
\text { último ano da } \\
\text { graduação? }\end{array}$} & \multicolumn{2}{|c|}{$\begin{array}{c}\text { Já cursou alguma } \\
\text { disciplina de } \\
\text { Contabilidade Rural ou } \\
\text { correlata? }\end{array}$} & \multicolumn{2}{|c|}{$\begin{array}{c}\text { Já assistiu alguma } \\
\text { palestra seminário ou } \\
\text { mesmo leu sobre } \\
\text { Contabilidade Rural? }\end{array}$} \\
\hline & Sim & Não & Sim & Não & Sim & Não \\
\hline Média & $47,53 \%$ & $47,63 \%$ & $65,66 \%$ & $45,33 \%$ & $59,81 \%$ & $45,29 \%$ \\
\hline Mediana & $44,44 \%$ & $44,44 \%$ & $66,66 \%$ & $44,44 \%$ & $66,66 \%$ & $44,44 \%$ \\
\hline Máximo & $88,88 \%$ & $88,88 \%$ & $88,88 \%$ & $88,88 \%$ & $88,88 \%$ & $88,88 \%$ \\
\hline Mínimo & $11,11 \%$ & $11,11 \%$ & $33,33 \%$ & $11,11 \%$ & $11,11 \%$ & $11,11 \%$ \\
\hline Desvio Padrão & $2,09 \%$ & $1,78 \%$ & $2,09 \%$ & $1,73 \%$ & $2,14 \%$ & $1,74 \%$ \\
\hline
\end{tabular}

Fonte: Elaboração Própria

A média de acertos dos alunos que estão cursando o último ano da graduação e dos que estão em outros semestres é quase igual, o que se verifica na mediana e nos números máximo e mínimo, o que é justificável, pois dentro dos dois grupos há alunos que já tiveram contato com o assunto e também os que não tiveram. O desvio padrão apresentou uma pequena variação. 
A média de acertos apresentada pelos alunos que já cursaram a disciplina de contabilidade rural supera em mais de $20 \%$ a dos alunos que não cursaram, uma porcentagem aproximada à da mediana. Apesar do valor máximo ser o mesmo, o mínimo de acerto apresentado pelos alunos que cursaram a disciplina foi de 33,33\%, o único grupo que apresentou valor mínimo superior a $11,11 \%$. Este resultado era esperado, já que a ementa da disciplina aborda a maioria dos assuntos questionados. $\mathrm{O}$ desvio padrão apresentou aqui uma pequena variação também, inferior a $0,5 \%$.

A média de acertos apresentada pelos alunos que assistiram alguma palestra, seminário ou leu sobre o tema supera em quase $15 \%$ o dos alunos que não realizaram estas atividades, um pouco inferior ao apresentado por alunos que cursaram a disciplina.

É possível observar, a partir desse resultado, que os alunos que tiveram maior contato com o assunto apresentaram porcentagem de acerto superior aos demais, de forma que é possível afirmar que a disciplina ofertada aproxima o discente à necessidade de conhecimento específico sobre o tema.

4.4 Nível de Acerto, de Acordo com o Interesse no Assunto

O quarto tópico de análise dos resultados consiste em avaliar o nível geral de acertos das questões elaboradas para testar o conhecimento dos alunos sobre particularidades da Contabilidade Rural com relação ao interesse apresentado pelos respondentes sobre o assunto. Os resultados são consolidados na Tabela 5.

Tabela 5: Nível de acerto, de acordo com o interesse no assunto

\begin{tabular}{|c|c|c|c|c|}
\hline \multirow[b]{2}{*}{ Respostas } & \multicolumn{2}{|c|}{$\begin{array}{l}\text { Na sua opinião, nas grades } \\
\text { curriculares dos cursos de Ciências } \\
\text { Contábeis deveria haver a } \\
\text { disciplina de Contabilidade Rural? }\end{array}$} & \multicolumn{2}{|c|}{$\begin{array}{l}\text { Você faria uma pós-graduação ou } \\
\text { um curso de extensão na área? }\end{array}$} \\
\hline & Sim & Não & Sim & Não \\
\hline Média & $50,03 \%$ & $41,37 \%$ & $48,15 \%$ & $47,31 \%$ \\
\hline Mediana & $44,44 \%$ & $33,33 \%$ & $44,44 \%$ & $55,55 \%$ \\
\hline Máximo & $88,88 \%$ & $88,88 \%$ & $88,88 \%$ & $88,88 \%$ \\
\hline Mínimo & $11,11 \%$ & $11,11 \%$ & $11,11 \%$ & $11,11 \%$ \\
\hline Desvio Padrão & $1,87 \%$ & $1,95 \%$ & $2,09 \%$ & $1,76 \%$ \\
\hline
\end{tabular}

Fonte: Elaboração Própria

A média de acerto dos alunos que consideram importante a inclusão da disciplina na grade curricular da graduação foi superior a dos que não consideram, em 8,66\%, a mediana também foi superior, porém o máximo e o mínimo foram iguais com uma variação no desvio padrão inferior a $0,1 \%$. 
A média de acerto dos alunos que fariam uma especialização na área foi quase a mesma dos que não fariam e surpreendentemente a mediana dos que não fariam foi superior a dos que fariam. Conforme apresentado nas questões anteriores as porcentagens referentes ao máximo e mínimo foram iguais com uma pequena variação no desvio padrão.

É possível observar que o respondente apresentar interesse no tema não foi suficiente para influenciar a porcentagem de acerto no questionário, diferindo da relação com os graduandos que efetivamente cursaram a disciplina. 


\section{CONCLUSÃO}

A Contabilidade Rural apresenta uma série de particularidades, como o prazo utilizado como exercício social, a mensuração dos ativos biológicos, a forma como deve ocorrer a amortização, depreciação e exaustão em seus ativos, o que demanda um tratamento diferenciado para cada um de seus itens.

O presente estudo teve como objetivo verificar o conhecimento dos graduandos da UnB sobre estas particularidades apresentadas pela Contabilidade Rural.

Foi realizada a aplicação de uma adaptação do questionário utilizado por Costa, Libonati e Rodrigues (2004), presencialmente nas salas de aula e de forma eletrônica, via formulário no Google Drive, apenas para alunos cursando a graduação em Ciências Contábeis e Atuariais. A análise do resultado foi realizada a partir de uma comparação entre o perfil dos respondentes e nível de acerto e o nível de acerto relacionado ao interesse apresentado pelo aluno na área.

Feita a análise do questionário respondido pelos graduandos do curso, conclui-se que os respondentes que cursaram a disciplina ou que de alguma forma tiveram contato com o tema apresentaram percentual de acerto das questões superior aos demais. $\mathrm{O}$ interesse demonstrado pelo aluno no assunto não interfere significativamente sem seu percentual de acerto. Portanto, é possível aferir que não basta apresentar interesse acerca do tema, é necessário que os alunos cursem a disciplina para obter conhecimento significativo sobre Contabilidade Rural.

As questões que se referiam a classificação de itens relacionados ao tema em um balanço patrimonial apresentaram menor percentual de acerto, com exceção da questão 8, única a apresentar exemplos do que deveria ser classificado. Conforme esperado, as questões que poderiam ser respondidas apenas com conhecimentos obtidos em contabilidade geral apresentaram maior percentual de acerto. Expondo o baixo conhecimento dos alunos sobre o tema, já que a média geral de acerto foi de $47,60 \%$;

Apesar da maioria dos alunos 71,96\% considerarem importante a inclusão da disciplina na grade curricular do curso, apenas 34,46\% fariam uma especialização na área. Demonstrando que apesar de perceberem a importância atribuída ao tema, os graduandos têm pouco interesse no assunto.

Em comparação ao estudo de Costa, Libonati e Rodrigues (2004), que concluiu que não havia na época percepção dos contadores da cidade estudada sobre o tema e que $92,86 \%$ dos respondentes consideraram importante a inclusão da disciplina nas grades curriculares é possível observar que o resultado foi semelhante ao deste estudo, pois apesar de não 
conhecerem o suficiente sobre o assunto os alunos também consideraram importante o estudo da disciplina.

A limitação deste estudo consiste na dificuldade de aplicação do questionário para toda a comunidade acadêmica, não sendo possível estender os resultados obtidos a todos graduandos de Ciências Contábeis da Universidade de Brasília.

Para realização de pesquisas futuras, sugere-se que seja realizado uma análise do conhecimento sobre essas especificidades com contadores formados atuantes na área, de maneira que seja possível aferir se há obediência às particularidades apresentadas pela Contabilidade Rural nas demonstrações das entidades por eles atendidas. 


\section{REFERÊNCIAS}

BLUESOFT. FERREIRA, Renan. Diferença entre amortização, depreciação e exaustão. 26 de out. 2015. Disponível em:

$<$ https://blog.bluesoft.com.br/2015/10/diferenca-entre-amortizacao-depreciacao-e-exaustao/>. Acesso em: 22 jan. 2018.

BRASIL. Decreto-Lei n.7.988, de 22 de setembro de 1945. Dispõe sobre o ensino superior de ciências econômicas e de ciências contábeis e atuariais. Disponível em:

$<$ http://www2.camara.leg.br/legin/fed/declei/1940-1949/decreto-lei-7988-22-setembro-1945417334-publicacaooriginal-1-pe.html>. Acesso em: 22 jan. 2018.

BRASIL. Ministério da Agricultura, Pecuária e Abastecimento. Revista de política Agrícola n1-2008. Disponível em: < http://www.agricultura.gov.br/assuntos/politica-agricola/todaspublicacoes-de-politica-agricola/revista-de-politica-agricola/revista-de-politica-agricola-n12008.pdf/view>. Acesso em: 22 jan. 2018.

BRASIL. Ministério da Agricultura, Pecuária e Abastecimento. Série histórica BCA resumida 1997-2016. Disponível em: $<\mathrm{http}$ ://www.agricultura.gov.br/assuntos/relacoesinternacionais/documentos/estatisticas-do-agronegocio/serie-historica-bca-resumida-19972016.xls/view>. Acesso em: $21 \mathrm{dez} .2017$

BRASIL. Portal Brasil. Agronegócio alcança superávit comercial de US\$ 7,1 bi em abril. Brasília, 09 mai. 2016. Disponível em: < http://www.brasil.gov.br/economia-eemprego/2016/05/agronegocio-alcanca-superavit-comercial-de-us-7-1-bi-em-abril>. Acesso em: 22 jan.2018.

CALDERELLI, Antonio. Enciclopédia Contábil e Comercial Brasileira, 28. ed. são paulo: cetec, 2003.

COMITE DE PRONUNCIAMENTOS CONTÁBEIS (CPC). CPC-04: Ativo Intangível. Brasília, dez. 2010. Disponível em:

$<$ http://static.cpc.mediagroup.com.br/Documentos/187_CPC_04_R1_rev\%2008.pdf >.Acesso em: 22 jan. 2018.

COMITÊ DE PRONUNCIAMENTOS CONTÁBEIS (CPC). CPC-27:Ativo Imobilizado. Brasília, jul. 2009. Disponível em:

$<$ http://static.cpc.mediagroup.com.br/Documentos/316_CPC_27_rev\%2008.pdf $>$. Acesso em: 22 jan.2018.

COMITÊ DE PRONUNCIAMENTOS CONTÁBEIS (CPC). CPC-29:Ativo Biológico e Produto Agrícola. Brasília, set. 2009. Disponível em:

$<$ http://www.cpc.org.br/CPC/Documentos-

Emitidos/Pronunciamentos/Pronunciamento?Id=60>. Acesso em: 22 jan. 2018.

COMITÊ DE PRONUNCIAMENTOS CONTÁBEIS (CPC). CPC-46: Mensuração do valor justo. Brasília, dez. 2012. Disponível em: <http://www.cpc.org.br/CPC/DocumentosEmitidos/Pronunciamentos/Pronunciamento? Id=78.> Acesso em: 22 jan.2018 
COSTA, M. dos S.; LIBONATI, J. J.; RODRIGUES, R. N. Conhecimentos sobre Particularidades da Contabilidade Rural: Um Estudo Exploratório com Contadores da Região Metropolitana de Recife. ConTexto - Revista do Programa de Pós-Graduação em Controladoria da UFRGS, RS, v. 4, n. 7, $2^{\circ}$ semestre, 2004. Disponível em: $<$ http://seer.ufrgs.br/index.php/ConTexto/article/view/11275/6665>. Acesso em: 22 jan. 2018.

CREPALDI, S. Contabilidade Rural: Uma Abordagem Decisorial. 5a . ed. São Paulo: Atlas. 2011 p 416.

CREPALDI, Silvio Aparecido. Contabilidade Gerencial. Teoria e Prática. 3. ed. São Paulo: Atlas, 2007.

Da EFE. Brasil será o maior exportador agrícola mundial em 2024, dizem OCDE e FAO. G1. 2015. Disponível em:<http:/g1.globo.com/economia/agronegocios/noticia/2015/07/brasil-sera-maiorexportador-agricola-mundial-em-2024-dizem-ocde-e-fao.html $>$. Acesso em: 22 jan. 2018.

FURTADO, C. Formação Econômica do Brasil. 25a . ed. São Paulo: Nacional, 1995.

GIL, A.C. Métodos e técnicas de pesquisa social. 6 $^{\text {a }}$ edição. ed. São Paulo: Atlas, 2008.

GIMENES, R; GIMENES, F. Agronegócio Cooperativo: a transição e os desafios da competitividade. Revista de Ciências Empresariais da UNIPAR, Umuarama, PR, v. 7, n.1, p. 33-46, $1^{\text {o }}$ semestre, 2016. Disponível em:

$<$ http://revistas.unipar.br/index.php/empresarial/article/view/516/471>, Acesso em: 22 jan.2018.

IBGE. PIB sobe 1,0\% no primeiro trimestre de 2017. Brasília, 2017. Disponível em: $<$ https://censo2010.ibge.gov.br/noticias-censo.html?busca=1\&id=1\&idnoticia=3442\&t=pibsobe-1-0-primeiro-trimestre-2017\&view=noticia >. Acesso em: 22 jan. 2018.

IBGE. Produção da Pecuária Municipal 2016. Brasília, 2016. Disponível em: $<$ https://biblioteca.ibge.gov.br/visualizacao/periodicos/84/ppm_2016_v44_br.pdf $>$. Acesso em: 22 jan. 2018.

INTERNATIONAL ACCOUNTING STANDARDS (IAS). IAS 41: Agriculture. Jan. 2009. Disponível em: $<$ https://www.iasplus.com/en/standards/ias/ias41>. Acesso em: 22 jan. 2018.

IUDÍCIBUS, Sérgio de et al. Contabilidade Introdutória. São Paulo: Editora Atlas S.A., 2010.

LIBONATI, Jeronymo José. Modelo gerencial de apuração de resultado para empresa agrícola: enfoque do sistema de gestão econômica - GECON. 1996. Dissertação (Mestrado em Contabilidade) - Departamento de Contabilidade e Atuária, Faculdade de Economia, Administração e Contabilidade, Universidade de São Paulo, São Paulo, 1996. 
MACIEL, J. V. dos S; BOTELHO, D. R. Evidenciação do ajuste a valor justo na DVA por empresas que exploram ativos biológicos. In: $2^{\circ}$ CONGRESSO UnB DE CONTABILIDADE E GOVERNAÇA 2016. Brasília: CCG-UnB, 2016. Disponível em: <

http://soac.unb.br/index.php/ccgunb/ccgunb2/paper/viewFile/5315/1459>. Acesso em 22 jan. 2018.

MARION, José Carlos. Contabilidade Rural: contabilidade agrícola, contabilidade da pecuária, imposto de renda pessoa jurídica / José Carlos Marion.14.ed.- São Paulo: Atlas, 2014.

PELEIAS, I. R.; SILVA, G. P. da.; SEGRETI, J. B.; CHIROTTO, A. R. Evolução do ensino da contabilidade no Brasil: uma análise histórica. Revista Contabilidade e Finanças - USP, São Paulo, SP, ed. 30 Anos de Doutorado, p. 19-32, jun. 2007. Disponível em: $<$ http://www.scielo.br/pdf/rcf/v18nspe/a03v18sp.pdf>. Acesso em 22 jan. 2018.

Portal BLB Brasil, 2017. Contabilidade agropecuária: você sabe como funciona?

Disponível em: $<$ http://portal.blbbrasilescoladenegocios.com.br/contabilidade-agropecuaria/ $>$. Acesso em: 22 jan. 2018.

RECH, I. J. . Formação do valor justo dos ativos biológicos sem mercado ativo: uma análise baseada no valor presente. São Paulo, 2011 Tese (Doutorado em Controladoria e Contabilidade: Contabilidade) - Faculdade de Economia, Administração e Contabilidade, Universidade de São Paulo, São Paulo, 2012.

ROCHA, C. M.C. da; RESENDE, E. K. de; ROUTLEDGE, E. A. B; LUNDSTEDL, L. M. Avanços na pesquisa e no desenvolvimento da aquicultura brasileira. Revista Pesquisa Agropecuária Brasileira, Brasília, DF, v.28, n. 8, 2013. Disponível em: < http://www.scielo.br/scielo.php?script=sci_arttext\&pid=S0100-204X2013000800003>. Acesso em: 24 jan. 2018.

SILVA, A. C. da C. F.; MARTINS, G. V.; MACHADO, M. A. V. Adoção do valor justo para os ativos biológicos: análise de sua relevância em empresas brasileiras. Revista Universo Contábil, Blumenau, SC, v. 9, n.4, p. 110-127, 2013. Disponível em: $<$ http://proxy.furb.br/ojs/index.php/universocontabil/article/view/3552>. Acesso em: 22 jan. 2018.

SILVA, N.M.G. da; CESÁRIO, A. V.; CAVALCANTI, I. R. Relevância do agronegócio para economia brasileira atual. X Encontro de Iniciação à Docência. UFB-PRG, 2006. Disponível em:

$<$ http://www.prac.ufpb.br/anais/IXEnex/iniciacao/documentos/anais/8.TRABALHO/8CCSA DAMT01.pdf $>$ Acesso em: 22 jan.2018.

ULRICH, E. R. Contabilidade Rural e perspectivas da gestão do agronegócio. RACI Revista de Administração e Ciências Contábeis do Ideau, Getúlio Vargas, RS, v. 4, n.9, dez. 2009. Disponível em:

$<$ http://www.ideau.com.br/getulio/restrito/upload/revistasartigos/108_1.pdf $>$. Acesso em: 22 jan. 2018. 


\section{APÊNDICE 1 - QUESTIONÁRIO APLICADO PARA OS ALUNOS DE CIENCIAS CONTÁBEIS DA UNIVERSIDADE DE BRASÍLIA}

1. Você está cursando o último ano da graduação:

( ) $\operatorname{Sim}($ ) Não

2. Você já cursou alguma disciplina de Contabilidade Rural ou correlata?

( ) $\operatorname{Sim}$ ( ) Não

3. Você já assistiu alguma palestra/seminário ou mesmo leu sobre Contabilidade Rural?

( ) Sim ( ) Não

4. A literatura existente sobre a Contabilidade Rural aborda o assunto de forma objetiva e clara?

( ) $\operatorname{Sim}$

( ) Não

( ) Nunca li sobre o assunto

5. Numa atividade agrícola, com diversas culturas em períodos de colheitas diferentes, prevalece o ano agrícola com base em?

( ) Ano civil

( ) Cultura de maior representatividade

( ) 3 culturas de maior Representatividade

6. Cultura permanente em formação é classificada como?

( ) Ativo circulante

( ) Ativo Não-Circulante - Investimento

( ) Produtos Agrícolas

( ) Ativo Não-Circulante - Imobilizado

7. A depreciação passa a incidir sobre a cultura:

( ) A partir da $1^{\mathrm{a}}$ safra ( ) Depende da cultura ( ) Depende da opinião de um agrônomo 
8. Os gastos com benfeitorias rurais como "Estradas", "Açudes", "Cercas", "instalações" e "bebedouros" devem ser classificados como:

( ) Ativos Circulante

( ) Passivo Circulante

( ) Produtos Agrícolas

( ) Ativo Não-Circulante - Imobilizado

9. Relativo a pecuária, o plantel em crescimento deve ser classificado no:

( ) Ativo Circulante - Estoque

( ) Ativo Diferido

( ) Ativo Não-Circulante - Investimento

( ) Ativo Não-Circulante - Imobilizado

10. Custos históricos na Pecuária são considerados:

( ) Adequados ( ) Inadequados

11. Cultura temporária em formação é classificada como:

( ) Ativo Circulante - Estoque

( ) Ativo Diferido

( ) Ativo Não-Circulante - Investimento

( ) Ativo Não-Circulante - Imobilizado

12. As cotas de exaustão podem ser aplicadas em:

( ) Tratores, colhedeiras e aparelhos agrícolas

( ) Florestas e espécies vegetais destinadas ao corte

( ) Culturas em Formação

13. Reprodutores e matrizes são classificados no:

( ) Ativo Circulante - Estoque

( ) Ativo Diferido

( ) Ativo Não-Circulante - Investimento

( ) Ativo Não-Circulante - Imobilizado 
14. Na sua opinião, nas grades curriculares dos cursos de Ciências Contábeis deveria haver a disciplina de Contabilidade rural?

( ) Sim ( ) Não

15. Você faria uma pós-graduação ou um curso de extensão na área?

( ) $\operatorname{Sim}(\quad$ ) Não 